\title{
Grizzly Man and the Spiritual Life
}

\author{
Patrick Curry \\ (A draft of a paper for the Journal for the Study of Religion, Culture and Nature 43:3
}

(2010) pp. 206-219)

Abstract: The story of Timothy Treadwell, as portrayed in Werner Herzog's film (2005), provides a basis for a critique of two opposing attitudes and programmes which can be identified, in broad metaphysical terms, as spiritual idealism and scientific materialism. I criticize the former, inferring from Treadwell's fate the danger - for spiritual seekers, directly, and for scholars, indirectly - of trying to be-atone or achieve absolute unity with the beloved. I then recommend a radical but viable middle way, grounded in our embodied, imperfect, unstable, liminal nature - a view clearly evident in aboriginal and folk wisdom traditions but also articulated by philosophers including Merleau-Ponty, Plumwood, Abram, Snyder and Bateson.

Timothy Treadwell is best known to most people from 'Grizzly Man', a documentary made by Werner Herzog in 2005. Treadwell lived with wild Alaskan grizzly bears (Ursus arctos horribilis) for thirteen summers before he and his girlfriend, Amie Huguenard, were killed and eaten by one in 2003. Herzog's movie incorporates some of the many hours of footage recorded by Treadwell which clearly show that what he did, however inadvisable, was remarkable. ${ }^{1}$ My concern here, however, is neither with Treadwell himself nor with the movie, but rather with the implications of this tragic story both for scholars of religion, culture and nature and for spiritual seekers seeking to navigate those deep waters.

Watching the film, one is immediately alerted to the existence of a possible problem by Treadwell's attitude to the bears: his intense sentimentality, his self-mythologisation, and his issues, so to speak, with boundaries. 'I'm in love with my animal friends. I'm in love with my animal friends! In love with my animal friends. I'm very, very troubled. It's very emotional.' And that emotion is wrapped up in a cause, which he defines as 'struggling against civilization itself.'

It struck me, listening to Treadwell, that such crusading sentimentality was covertly but intimately connected with the casual brutality of the bears' enemies - sadodispassionate, to use Teresa Brennan's apt term (1993) - against whom Treadwell was reacting: the hunters, poachers, and to some extent, wildlife service managers. Herzog too is ideologically close to that party, if more than usually articulate, and his voice is unmistakeably anthropocentric:

what haunts me is that in all the faces of all the bears that Treadwell ever filmed, I discover no kinship, no understanding, no mercy. I see only the overwhelming indifference of nature. To me, there is no such thing as a secret world of the bears.

\footnotetext{
${ }^{1}$ The film. It is easily available, and there are many sources on the internet. In addition to basic information, two interesting commentaries are those by wild bear expert Charlie Russell (http://cloudline.org/treadwell.html) and John Rogers (http://www.katmaibears.com/timothytreadwell.htm), both accessed 14 September 2009. Quotations herein by Treadwell, Herzog and Sven Haakanson are taken directly from the film.
} 
And this blank stare speaks only of a half-bored interest in food. But for Timothy Treadwell, this bear was a friend, a saviour.

Treadwell thus prizes non-human 'animals' living in 'wilderness' over all human 'civilisation', and Herzog takes the opposite position. But this polarisation disguises what is shared by both parties: a foundational distinction between 'nature' and 'humanity', enabling the tendentially absolute valorisation of one over the other. I cannot delve here into the Platonic-Christian-Cartesian provenance of this dogma, almost certainly the single most destructive discourse ever to have appeared in this beautiful but benighted world. Although many analysts could be mentioned in this connection, some of whom I discuss below, the late Val Plumwood (1993, 2002) remains one of the most acute. (See also Curry 2003, 2007 and 2008.) The point is that although the sentimentalists like Treadwell do much less immediate harm than the brutalists, both relate to 'nature' in ways with destructive effects (sometimes lethal, although much more often for the bears than for humans) on all concerned. Both, I argue, are dead ends.

The most sensible statement in the film was made by the Native American curator of the Alutig Museum, Sven Haakanson, who observed that Treadwell

tried to be a bear.... For us on the island you don't do that. You don't invade their territory.... For me, it was the ultimate in disrespecting the bear and what the bear represents.... If I look at it from my culture, Timothy Treadwell crossed a boundary that we have lived with for 7000 years.

In striking contrast to the views of both Treadwell and Herzog (but nearly inaudible, thanks to their louder voices), here is the basis for a viable middle way, one which refuses both poles and offers a way to live with the Other(s). True, Haakanson refers to an important boundary. To anticipate my argument, however, it is a boundary that permits (and indeed, enables) relationships - ideally, respectful relationships - not the mutually exclusive and exhaustive split characteristic of Cartesianism. Nor is it foundational, like the Cartesian approach; rather, it occurs within the world of more-than-human nature.

Such wisdom is deeply rooted in the world's remaining, relatively intact indigenous cultures. That is not to say, of course, that it is flawless or incorruptible. But at the heart of genuine cultural sustainability is the fluid but integrally-linked mixture of local or bioregional-scientific ecological wisdom, spiritual values and corresponding ritual practices, and socio-political ethics which comprises traditional ecological knowledge (hereafter TEK). TEK 'represents experience acquired over thousands of years of direct contact with the environment.' A joint report by the Worldwide Fund for Nature and Terralingua crossmapped the world's ecoregions of the highest biological diversity with the areas of greatest cultural and linguistic diversity. More than $80 \%$ of such diversity is supplied by indigenous peoples, even though they constitute only $5 \%$ of the global population. The result strongly suggests that biological and cultural diversity are interdependent: where TEK survives and thrives, so does biodiversity, and where it suffers or disappears, so do ecosystems (Oviedo and Maffi 2000).

In this respect, critiques of 'the ecological Indian' as simply another instance of the Myth of the Noble Savage function as a rear-guard defence of anti-ecological modernism. They should not be allowed to obscure the extent to which our survival depends on collectively rediscovering how to live 'with the Earth on the Earth's terms' (Kane 1998: 14; see also Snyder 1990, Deloria 2000 and Plumwood 2002: 218-35).

\footnotetext{
${ }^{2}$ http://www.idrc.ca/en/ev-84401-201-1-DO TOPIC.html (accessed 10.8.09)
} 
Haakanson's verdict is of a piece with one of the sacred stories of the Sweet Grass Cree, who inhabit Western Canada. In this story, a young hunter met and began living with a strange young woman who eventually took him to meet her people:

When he had been there a long time, and spring had come, then he knew that she, the woman, as it seemed to him, whom he had to wife, was a bear, and that also the old man and the old woman were bears. And he was sorry that he could not always be with them (Bloomfield 1993: 61). ${ }^{3}$

Or as the poet Robert Bringhurst (2009: 235) put it in a poem about ursine-human relations, 'You can have what you want but can't have it for long.'

Gary Snyder's words, written well before Treadwell's death, are also apropos: reconnecting with the wild, he says, 'requires embracing the other as oneself and stepping across the line - not "becoming one" or mixing things up but holding the sameness and difference delicately in mind.' Even more pointedly, he advises: 'do not be too hasty in setting out to "become one with"' $(1990: 192,120) .{ }^{4}$

Western traditions of folk and fairy-tales with premodern roots teach the same lesson: you may, exceptionally, be able to visit Faërie but you cannot, as a human being, stay there; and it is dangerous to try. (See Tolkien 2005 and Flieger and Anderson 2008.) Thinking of Treadwell, I am sharply reminded of W.H. Auden's (1970: 149) apposite warning:

All folk tales recognize that there are false enchantments as well as true ones. When we are truly enchanted we desire nothing for ourselves, only that the enchanting object or person shall continue to exist. When we are falsely enchanted, we desire either to possess the enchanting being or be possessed by it.

\section{Spiritual Cultures of Death}

Taking Treadwell and his opponents as exemplars of what has been well-described as "two vying "monisms" (Jonas 1982: 16), idealism (or spiritualism) and materialism, I am going to recommend a radical middle way. As Bateson (1987: 51-2) remarked towards the end of his life, however, the problem as a whole

is not entirely symmetrical. . While I disbelieve almost everything that is believed by the counter-culture, I find it more comfortable to live with that disbelief than with the dehumanizing disgust and horror that conventional occidental themes and ways of life inspire in me.

These materialist and mechanist themes lie at the heart of what Lewis Mumford $(1967,1970)$ called 'the megamachine', with all its ecocidal effects. It is their advocates - the programmatic modernists, dogmatic secularists and acolytes of scientism, together with the ranks of career bureaucrats, managers and administrators responsible for institutional dissemination - who should principally be held to account for those effects.

As I have already suggested, however, the contrast with the metaphysical idealism of the counterpole is potentially misleading. So too, relatedly, is the 'spiritual' dimension to the alternative I am recommending. It is therefore important not to lose sight of the heavy weight

\footnotetext{
${ }^{3}$ With thanks to Mark Dickinson for drawing this story to my attention.

${ }^{4}$ See also pp. 166-86 on "The Woman Who Married a Bear".
} 
of religious traditions whose adherents have also happily enlisted in the ongoing war on the body, the feminine, and the Earth. Plumwood (1992) has brilliantly diagnosed the poison, 'rotten with perfection', to borrow Kenneth Burke's excellent apophthegm (1966: 16), at the heart of Platonism. (See also Lloyd 1984 and Cavarero 1995.) Another taproot is the discourse that may be very broadly called 'Gnostic', enormously influential both within and outside Christianity, which embodies in various ways a common fear and contempt of the body, the feminine, the Earth, and 'darkness', all of which salvation requires the devotee to transcend and escape or negate the self as quickly and thoroughly as possible. As Montaigne observed, with characteristic sanity, regarding Christian martyrs suffering bodily torture with equinamity: 'we have to admit that there is some change for the worse in their souls, some frenzy, no matter how holy' (1991: 390). Yet in Christianity, this tendency coexists with the potentially grounding implications of the Incarnation (kenosis) and a spiritual practice centred on one's ongoing relationship with God.

This is not only a 'Western' problem. For Advaita Vedanta too, the material world (regarded - no surprise - as feminine) is a deception and illusion, like 'dog vomit to be cast out in disgust by the discriminating knower.' Similarly, Jains are encouraged to achieve a mystical state to the same world-denying end. (See the excellent discussion in Jain and Kirpal 2009.) The same ascetic metaphysic and ethos are to be found in Buddhism as well, affirmations of the Middle Way, and of nirvana as samsara (to quote the Heart Sutra) notwithstanding. As Snyder has remarked, 'Otherworldly philosophies end up doing more damage to the planet (and human psyches) than the pain and suffering that is in the existential conditions they seek to transcend' (1990: 196). Ultimately, however, the tension between world-denying spiritual absolutism and what I am calling a radical middle way runs not so much between the major religions as through most of them.

Nor can this issue be dismissed as merely historical or foreign exoticism. The most influential New Age philosophy today is probably Ken Wilbur's grand neo-Hegelian synthesis, which is saturated with a Gnostic, evolutionary, hierarchical and anthropocentric drive to realise 'Cosmic Consciousness'. What, then, could be less surprising than to find that Wilbur denigrates relational, ecological and feminist spiritualities as inferior? (For a critical antidote, see Ferrer 2002.) And a great deal of this pernicious sort of ideology has found its way into systems of esotericism and occultism, both old and new, whose 'spirituality' belies their underlying concern: personal power and 'spiritual' ambition. As Byron observed, 'when a man talks of system, his case is hopeless'; whether that system is occult or exoteric, spiritual or material, overtly or merely implicitly metaphysical, is secondary. (There is no room to develop the point here, but power is the top priority of the magic which both historically and philosophically fed directly into the formation of modern materialist science; see Curry, forthcoming in 2011.)

\section{The Metaphysics of a 'Middle Way'}

The two polarised extremes in the story of 'Grizzly Man' can be assimilated without significant metaphysical loss to the millenia-long struggle between idealism and materialism. Many authors have usefully identified these poles in various ways: 'spiritual idealism' vs. 'scientific determinism' (David Abram), 'unity' vs. 'hyperseparation' (Val Plumwood), 'the rational' vs. 'the sensible' (Maurice Merleau-Ponty), 'supernaturalism' vs. 'mechanism' (Gregory Bateson), 'naïve unity' vs. 'reductionism' (Paul Ricoeur), and 'the lyric' vs. 'the technological' (Jan Zwicky). I shall go deeper into some of these discussions in what follows. But I refrain from any critique of the polemics of Dawkins, Dennett, Hitchins and similar current representatives of scientific materialism. There is good reason to suspect them, but 
John Gray (2008), Mary Midgley $(1992,2001)$ and Terry Eagleton $(2006,2009)$ have already exposed the New Atheists' theological ignorance, philosophical shallowness and cryptoreligiosity (and therefore hypocrisy). Another consideration is simply that of space, so I want to concentrate here on the 'spiritual' pole.

In this context, what 'Grizzly Man' conveys is that spiritual unity or Oneness is not a viable or helpful corrective to the icy objectification of 'nature', nor to materialists' attempts to reduce subjectivity to that pole. The kind of romantic move for which Treadwell serves well as an exemplar is rather a counter-reductionism which is ultimately equally counterproductive. Why? Because it too corroborates and legitimates the metaphysical split that is at the very root of the problem. As Bateson put it, 'These two species of superstition, these rival epistemologies, the supernatural and the mechanical, feed each other' (1987: 51). More recently, regarding scientific discourse (privileging abstract objectivity) and New Age discourse (privileging subjectivity), David Abram has pointed out that

by prioritizing one or the other, both of these views perpetuate the distinction between human 'subjects' and natural 'objects,' and hence neither threatens the common conception of sensible nature as a purely passive dimension suitable for human manipulation and use. While both of these views are unstable, each bolsters the other; by bouncing from one to the other - from scientific determinism to spiritual idealism and back again - contemporary discourse easily avoids the possibility that both the perceiving being and the perceived being are of the same stuff, that the perceiver and the perceived are interdependent and in some sense even reversible aspects of a common animate nature, or Flesh, that is at once both sensible and sensitive (1996: 6667; emphasis in original).

(I would add that the sentimental yearning for unity, implied in what Abram terms 'spiritual idealism', lends itself very well to ideological exploitation by instrumental capital, e.g. sentimental ditties about how we are all One, sung with a tear in the eye by various worldeaters, big and small, before going back to work.)

Maurice Merleau-Ponty's late philosophy contributes profoundly to an understanding of these issues. As is well-know, he was the philosopher par excellence of embodiment. But to identify that condition with the materialist pole of the Cartesian split wuld be a grievous misunderstanding. He used the term 'Flesh' to denote a metaphysics that resolutely refuses to be corralled into either the subjectivist or the objectivist camp. It describes a chiasmic crisscrossing whereby 'subject' and 'object', 'body' and 'mind', 'self' and 'world', and 'inner' and 'outer' constitute dualities but not a dualism (see Reynolds 2004:58). None are reducible to their constitutive others; nor, however, are they possible without each other. Each pole not only entails the other but enables, indeed requires, the other. Yet each also limits the other, preventing pure realization in either direction. The relational pluralism of this motile inbetweenness means that neither identity or unity, nor alterity or hyperseparation, can ever be attained in any pure or permanent way: 'what enables us to center our existence is what also prevents us from centering it completely...' (Merleau-Ponty 1962: 85). ${ }^{5}$ It follows, I think, that any attempt to achieve a monist purity (in either direction) is ill-advised at best and has tragic consequences, as in Treadwell's case, at worst.

\footnotetext{
${ }^{5}$ See also Merleau-Ponty 1968, and, for a recent discussion, my 2010b, where I argue for an integral affinity between Merleau-Ponty's chiasmic Flesh and metaphor as understood by Paul Ricoeur, insofar as the latter is equally 'tensive' and in the same way.
} 
Graham Harvey's (2006) study of animism, combining insights from religious studies, anthropology and philosophy, is grounded in the same tensive and liminal place. Similarly, Jan Zwicky's intermediary 'domestic' - which is where we actually live - mediates 'the essential tension' between lyric desire (unachievable but unavoidable) on the one hand and the otherwise destructive instrumental capacity for technology on the other (1992: 258; see also Curry 2010c). ${ }^{6}$

\section{Plumwood's Contribution}

Val Plumwood has contributed several important related perspectives in this context. ${ }^{7}$ First, she has emphasised that the

oppositional formulation of spirit versus matter renders invisible the important concept of a materialist spirituality which does not invoke a separate spirit as an extra, independent individualized ingredient but rather posits a richer, fully intentional non-reductionist concept of the earthly and the material (2002: 222).

In the same work she not only critically analyzes value-laden hierarchical dualism but articulates a 'materialist spirituality' or 'dialogical materiality' - a perspective which converges, from an ecofeminist direction, with Merleau-Ponty's understanding of lived bodies.

Plumwood has also argued for a 'relational self' as against both 'radical exclusion' - a conception of the self as self-contained and the other as wholly alien - and 'incorporation', which denies difference and treats the other as a form of the same or self: precisely Treadwell's mode. Against that - in an exact but independent echo of both Haakanson and Snyder - she urged the need for 'recognising kinship and recognising difference' (1993: 155). (Kinship, not identity - which again, is the same theme so often found in aboriginal and indigenous contexts.)

Elsewhere in her work, Plumwood criticized the weakest form of Deep Ecology, the very one favoured by Arne Naess and some of his progeny, Ecosophy T, namely, the spiritual quest for 'Self-realization'. There are more aspects of this idea than can be discussed in detail here (see Curry 2006: 71-81). One is particularly relevant is this context, however: the quest for a meta-identity sublating humanity, nature and (in effect) God in an inflated, quasiHegelian 'Big Self'. All the problematics I have already identified attend any such attempt. That includes two also identified by Plumwood (1991, 2000): not only the way Ecosophy $T$ invites mere egoism writ large, but the way it facilitates a distinctly New Age capital-friendly program when commodification itself is integral to the problem. I certainly don't mean to suggest that criticisms dispose of Deep Ecology. But to the extent that Ecosophy T has effectively replaced the original theory in the minds and lives of its public, Plumwood's critique cannot be ignored. (That extent can, of course, be debated.)

I was recently reminded of the issue of incorporation into a Self by the finale of Peter Brook's most recent play, 'Eleven and Twelve'. A Sufi parable is reverentially related by the Master concerning a group of butterflies drawn to a flame. Finally, one gathers up his

\footnotetext{
${ }^{6}$ The contrast between these philosophies and Heidegger's inflated and reductive Dasein, with its anthropocentric valorisation of human language and eschatalogical conception of history, all too perversely realised in his time, is surely striking. (See Westling 2007.)

${ }^{7}$ See my 2010a for a related recent personal discussion.
} 
courage, flies into the flame, and is extinguished, whereupon their master announces: 'This one has finally understood. And he is the only one who knows. And that is all.' We may set aside the dramatic failure of such portentousness, and the convenience for the Master, who manages to hold himself back, but not another unfortunate irony: the violence at the heart of this paean to pacifism. What better encapsulation could there be of the Platonic culture of death that Plumwood (1992), with passion and precision, named as such? Spiritual purity, the transcendent Absolute and the absoluteness of transcendence, martyrdom: all its lineaments are present. And it is integral to both Brook's play and the philosophy that informs it, not only that it is such a man's world, but that all traces of the feminine have been carefully excised - along with nature and embodied life as such.

\section{What Can We Learn?}

In the end, at the risk of sounding callous, it seems to me that the fatal bear called Treadwell's bluff, so to speak: 'You want unity? Ok... ${ }^{8}$ This risk is worth taking because there is a serious point at stake here: Treadwell, in a sense, succeeded. He did, literally, become one with a bear, although he was no longer there to appreciate the fact. But I shall assume this was not an outcome he really wanted. More complexly, I am suggesting that that outcome was fundamentally a consequence not of his chosen object of desire (a bear) but of his mode. As Ames and Hall remark in their recent commentary on the Daodejing, 'The Daoist problem with desire does not concern what is desired, but rather the manner of the desiring' (2003: 42).

I have argued a largely negative case that the quest for unity is a mistake because it is impossible, destructive and self-destructive. In a word, we are relational - and a fortiori, ecological - beings. The same argument can be made in more positive terms, however. Borrowing the words of Jessica Benjamin and later quoted by Plumwood,

Experiences of 'being with' are predicated on a continually evolving awareness of difference, on a sense of intimacy felt as occurring between 'the two of us'. The fact that self and other are not merged is precisely what makes experience of merging have such high emotional impact (1985: 47; emphasis in original, Plumwood 1993: 156).

This point is not as paradoxical as it may sound. If self and other are merged, there is no longer a self (to experience) nor an other (to be experienced); hence there can be no merging (intimacy, closeness, wonder, etc.).

The same point can prevent a possible misunderstanding. What about the shaman in a bear dance: does he not become a bear in a way that cannot be reduced to cognitive 'belief' and mere epistemology? Certainly - but in a very different way to how Treadwell became a bear. The becoming animal of a shaman (for example) is relational precisely as Merleau-

\footnotetext{
${ }^{8}$ I'm aware of a certain lack of charity in my attitude to Treadwell, probably because I am a recovering seeker after romantic unity with sentimental tendencies myself. $\mathrm{He}$ was patently an innocent, so to speak, and terrible things often happen to innocents. So that is a failing on my part; but I do not think it changes my main point. I note too (as pointed out to me by Mark Dickinson) that Treadwell probably stood a better chance among the bears than among his own people; and that he was also, in part, a victim of sheer bad luck. Nor is it negligible (as Bron Taylor reminded me) that he had more than a decade of a richly meaningful and satisfying life with bears and, for all we know, they with him.
} 
Ponty and Ricoeur would lead us to expect: that is, the tensive middle of embodied metaphor (see Curry 2010b). The shaman both is and is not a bear, just as, in the classic example, Achilles both is and is not a lion. It is only because the shaman is not a bear that he can become one, and in becoming a bear simultaneously remain a man. ${ }^{9}$

In sum, then, acting out the desire to attain perfect unity or become one with, to be dissolved in or taken up into, to realise a state of perfect or complete or permanent union with anything, partakes of an attitude which is hostile to relationality en tout and, as such, antiecological. Furthermore, metaphorically speaking (and none the less truthfully for that), the actor runs a serious risk of being killed and eaten, in a process doubly destructive: both suicidal, because you will cease to exist as such, and homicidal, because so too will the beloved cease to exist for you. This is the case, I suggest, whether the beloved is another human being, a nonhuman animal, a god, God, the Godhead, Being or the Absolute. Those for whom the latter spiritual entities are meaningless need not follow the argument that far, of course. But people for whom divine beings are realities should remember that even in such a context, the gods themselves remain particular and relational beings; in which case, the danger, albeit metaphysical, remains.

Why should this be the case? Because in a forced either/or choice between mutually exclusive polarities, 'neither the either nor the or' is a place where people can live', and 'living as we do, in the middle', we are its creatures: imperfect, changeable and dynamic, somewhere between and different from any two genuine polarities that can be named (Le Guin 1989: 30, 98, my emphasis). Any attempt to fully realise (make real) either pole can therefore only 'succeed' by failing, so to speak, while potentially wreaking personal and collective havoc along the way.

Needless to say, any riposte that union with spiritual or transcendental reality escapes my critique of such attempts because it is 'primary' or 'underlies' physical reality would be to simply re-assert, or ignore, what I have been at pains to deny: that either the 'spiritual' or the 'material' can ever be foundational, or that the distinction between them is. The lesson contained in Treadwell's story cannot be dismissed or contained so easily as that.

The middle way here entails the radical equality of nondual 'emptiness'. As embodied beings (of whatever kind, and however embodied) we are all in the same existential situation and therefore share profound affinities. These mean we can all potentially empathize with and perhaps help each other; but that situation includes our respective boundaries, whose distinct reality should be acknowledged and respected. There is much more to etiquette than mere manners.

Nor, appropriately, is this understanding a single perspective. It is where many cross but also remain distinct. Among the approaches of those whom I have quoted are ones engaged in ecological phenomenology (Abram, incorporating Merleau-Ponty), philosophical animism (Plumwood and Harvey), Buddhism (Mahayana, especially Madhyamika) arguably meeting in Snyder's Buddhist animism (Taylor 2005: 1563, and see Taylor 2010: 17-18) - as well as philosophical Daoism, Heraclitus's panta rhei, Buber's I-Thou philosophy, and Hillman's metapsychology of 'soul.' Viverios de Castro explicitly discusses perspectivism (see Viveiros de Castro 2004, as well as Curry 2003 and 2008).

Of course, these discourses too are vulnerable to a dogmatic interpretation - even the one that famously begins, 'The Dao that can be put into words is not really the Dao'. Despite the best efforts of mon(othe)ists, no discourse, whether sacred or secular, can successfully dictate the conditions of its own apprehension and use. So it is certainly possible (if difficult) to imagine the Dao de Ching or the Mulamadhyamakakarika being touted as the absolute

\footnotetext{
${ }^{9}$ For a discussion of this and related issues - including the obvious one of LévyBruhl's mentalités - see my discussion in Curry $2010 \mathrm{~b}$.
} 
truth and final answer. This is because all discourses constrain, inform and influence: a point that is equally integral to the tensive, messy openness of life (which the second text just named terms 'dependent co-origination') that I am defending. It would therefore be fatuous to pretend that they are all equal with respect to what we do. It is no coincidence that monist discourses figure so prominently in the current and ongoing slaughter of innocents.

In contrast, pluralist discourses that recognize and respect the messy, middling complexity of life are relatively resistant to being mobilized on behalf of campaigns for single-minded purity, whether religious, political or social. It is therefore not suprising that the ones I have advocated or mentioned here, despite comprising a rich array, constitute a distinctly marginal and counter-hegemonic minority overall. They should be seen in the context of the overwhelming historical dominance, not only in the 'West' but increasingly globally, of the "two vying "monisms" (again, following Jonas) of transcendental spiritualism and scientific materialism. Both have many forms but the obvious overarching exemplars, as I have suggested, are monotheism and techno-science.

Of these two, I have already conceded that adherents of the latter are now globally more powerful and destructive. Nonetheless, I would like this paper to sound a warning to those tempted by the path of transcendence or spiritual union as 'the answer'. Not only is it ineffective at best and counter-productive at worst, but insofar as self (spirit, etc.) and world (body, etc.) are, in lived practice, inseparable, to try to 'transcend' the latter is an act of selfmutilation and potentially suicide. This is the true import of the cautionary tale of 'Grizzly Man', and Timothy Treadwell's best legacy.

\section{REFERENCES}

Abram, David. 1996. The Spell of the Sensuous: Perception and Language in a MoreThan-Human World (New York: Vintage Books).

Auden, W.H. 1970. A Certain World: A Commonplace Book (New York: The Viking Press).

Bateson, Gregory and Mary Catherine. 1987. Angels Fear: An Investigation into the Nature and Meaning of the Sacred (London: Rider).

Benjamin, Jessica. 1985. 'The Bonds of Love: Rational Violence and Erotic Domination', in Hester Eisenstein and Alice Jardine (eds.), The Future of Difference (New Brunswick NJ: Rutgers University Press).

Bloomfield, Leonard (ed.). 1993. Sacred Stories of the Sweet Grass Cree (Saskatoon: Thistledown Books).

Brennan, Teresa. 1993. History after Lacan (London: Routledge).

Bringhurst, Robert. 2009. Selected Poems (Kentville: Gaspereau Press).

Burke, Kenneth. 1966. Language as Symbolic Action: Essays on Life, Literature and Method (Berkeley: University of California). 
Cavarero, Adriana. 1995. In Spite of Plato: A Feminist Rewriting of Ancient Philosophy, transl. Serena Anderlini-D’Onofrio and Aine O'Healy (New York: New York).

Curry, Patrick. 2003. 'Re-Thinking Nature: Towards an Eco-Pluralism', Environmental Values 12.3: 337-360.

Curry, Patrick. 2006. Ecological Ethics: An Introduction (Cambridge: Polity Press).

Curry, Patrick. 2007. 'Post-Secular Nature: Principles and Politics', Worldviews: Environment, Culture, Religion 11.3: 284-304.

Curry, Patrick. 2008. 'Nature Post-Nature', New Formations 26: 51-64.

Curry, Patrick. 2010a. 'Some Remarks on Val Plumwood', Green Letters 12.

Curry, Patrick. 2010b. 'Embodiment, Alterity and Agency: Negotiating Antinomies in Divination', in Patrick Curry (ed.), Divination: Perspectives for a New Millennium (Farnham: Ashgate).

Curry, Patrick. 2010c. 'From Ecocriticism to Ecohumanities: an Essay-Review', Green Letters 13.

Curry, Patrick. 2011, forthcoming. 'On Not Saving Enchantment for Modernity', in Tom Crook and Mathew Feldman (eds.), Sacred Modernities: Rethinking Modernity in a Post-Secular Age (London: Continuum).

Daodejing: 'Making This Life Significant': A Philosophical Translation, ed. and transl. Roger T. Ames and David L. Hall. 2003. (New York: Ballantine Books).

Deloria, Jr.,Vine. 2000. ‘The Speculations of Krech', Worldviews 4.3: 283-93.

Eagleton, Terry. 2006. "Lunging, Flailing, Mispunching", London Review of Books (19.10.06).

Eagleton, Terry. 2009. Reason, Faith and Revolution: Reflections on the God Debate (Yale University Press).

Ferrer, Jorge N. 2002. Revisioning Transpersonal Theory: A Participatory Vision of Human Spirituality (Albany: SUNY Press).

Flieger, Verlyn and Douglas A. Anderson (eds.). 2008. Tolkien on Fairy-Stories (London: HarperCollins).

Gray, John. 2008. 'The Atheist Delusion', The Guardian (14.3.08).

Harvey, Graham. 2006. Animism: Respecting the Living World (New York: Columbia University Press). 
Jain, Andrea R. and Jeffrey J. Kirpal. 2009. 'Quietism and Karma: Non-Action as Non-Ethics in Jain Asceticism', Common Knowledge 15.2: 197-208.

Jonas, Hans. 1982. The Phenomenon of Life: Toward a Philosophical Biology (Chicago: University of Chicago Press).

Kane, Sean. 1998. Wisdom of the Mythtellers, $2^{\text {nd }}$ edn. (Peterborough: Broadview Press).

Le Guin, Ursula. 1989. Dancing at the Edge of the World. Thoughts on Words, Women, Places (London: Paladin).

Lloyd, Genevieve. 1984. The Man of Reason (London: Methuen).

Merleau-Ponty, Maurice. 1962. The Phenomenology of Perception, transl. Colin Smith (London: Routledge \& Kegan Paul).

Merleau-Ponty, Maurice. 1968. The Visible and the Invisible, ed. Claude Lefort, transl. Alphonso Lingis (Evanston: Northwestern University Press).

Midgley, Mary. 1992. Science and Salvation (London: Routledge).

Midgley, Mary. 2001. Science and Poetry (London: Routledge).

Montaigne, Michel de. 1991. The Complete Essays, transl. M.A. Screech (London: Penguin).

Mumford, Lewis. 1967, 1970. The Myth of the Machine, 2 vols. (New York: Harcourt Brace Jovanovitch).

Oviedo, Gonzalo and Luisa Maffi, with Peter Bille Larsen. 2000. Indigenous and Traditional Peoples of the World and Ecoregion Conservation: An Integrated Approach to Conserving the World's Biological and Cultural Diversity, a report by the WWF and Terralingua (Gland: the WWF, 2000).

Plumwood, Val. 1993. Feminism and the Mastery of Nature (London: Routledge).

Plumwood, Val. 1991. 'Nature, Self and Gender: Feminsim, Environmental Philosophy and the Critique of Rationalism', Hypatia 6: 10-16, 23-26.

Plumwood, Val. 2000. 'Deep Ecology, Deep Pockets, and Deep Problems: A Feminist Ecosocialist Analysis', in Eric Katz, Andrew Light, and David Rothenberg (eds.), Beneath the Surface: Critical Essays in Deep Ecology (Cambridge MA: MIT Press): 59-84.

Plumwood, Val. 2002. Environmental Culture: The Ecological Crisis of Reason (London: Routledge).

Reynolds, Jack. 2004. Merleau-Ponty and Derrida: Intertwining Embodiment and Alterity (Athens OH: Ohio University Press). 
Snyder, Gary. 1990. The Practice of the Wild (Berkeley: Counterpoint).

Taylor, Bron (ed.). 2005. The Encyclopedia of Religion and Nature, 2 vols. (Bristol: Thoemmes Continuum).

Taylor, Bron. 2010. Dark Green Religion: Nature Spirituality and the Planetary Future (Berkeley: University of California Press).

Tolkien, J.R.R. 2005. Smith of Wootton Major, ed. Verlyn Flieger (London: HarperCollins).

Viveiros de Castro, Eduardo. 2004. 'Exchanging Perspectives: The Transformation of Objects into Subjects in Amerindian Ontologies', Common Knowledge 10,3: 463-84.

Westling, Louise. 2007. 'Heidegger and Merleau-Ponty: Ecopoetics and the Problem of Humanism', in Fiona Beckett and Terry Gifford (eds.), Culture, Creativity and Environment: New Environmental Criticism (Amsterdam: Rodopi).

Zwicky, Jan. 1992. Lyric Philosophy (University of Toronto Press). 